\title{
Pengaruh Jarak Tanam dan Takaran Pupuk Kandang Babi terhadap Pertumbuhan dan Hasil Kacang Tanah (Arachis Hypogaea L.)
}

\author{
Ludovikus Nono $^{\mathrm{a}}$ dan Syprianus Ceunfin ${ }^{\mathrm{b}}$ \\ ${ }^{a}$ Fakultas Pertanian, Universitas Timor, Kefamenanu, TTU - NTT, Indonesia \\ ${ }^{b}$ Fakultas Pertanian, Universitas Timor, Kefamenanu, TTU - NTT, Indonesia.
}

\section{Article Info}

Article history:

Received 8 Desember 2018

Received in revised form 19 Desember 2018

Accepted 4 Januari 2019

DOI:

https://doi.org/10.32938/sc.v4i01.178

Keywords:

Jarak Tanam

Pupuk Kandang Babi

Arachis Hypogaea

\section{Abstrak}

Kacang tanah merupakan salah satu tanaman leguminose yang sangat berperan penting bagi kebutuhan pangan, tetapi memiliki nila ekonomi yang tinggi sehingga banyak yang menjadikan kacang tanah selain bahan pangan juga sebagai bahan baku industri. Penelitian in bertujuan untuk mengetahui pengaruh jarak tanam dan takaran pupuk kandang babi terhadap pertumbuhan dan hasil tanaman kacang tanah (Arachis hypogaea L.). Penelitian ini telah dilaksanakan pada bulan Desember 2016 - Maret 2017 di kebun percobaan Fakultas Pertanian Universitas Timor, dengan menggunakan Rancangan Acak Kelompok faktorial $3 \times 3$ diulang 3 kali. Faktor pertama adalah jarak tanam dengan tiga taraf yaitu: Jarak tanam $40 \mathrm{~cm} \times 20 \mathrm{~cm}$, Jarak tanam $40 \mathrm{~cm} \times 30 \mathrm{~cm}$, dan Jarak tanam $40 \mathrm{~cm} \times 40 \mathrm{~cm}$; faktor kedua adalah dosis pupuk kandang babi dengan tiga taraf yaitu: 0 t/ha, $5 \mathrm{t} / \mathrm{ha}, 10 \mathrm{t} / \mathrm{ha}$. Hasil penelitian menunjukkan tidak terjadi interaksi antar perlakuan takaran pupuk kandang babi dengan perlakuan jarak tanam terhadap semua parameter pengamatan kecuali pada parameter panjang akar. Pemberian pupuk kandang babi dengan takaran 10 t/ha menghasilkan biji kering per hektar terberat (1,72 t/ha.) dan berbeda nyata dengan kontrol. Pengaturan jarak tanam $40 \mathrm{~cm} \times 40 \mathrm{~cm}$ menghasilkan jumlah polong pertanaman $(20,37$ polong), biji kering per tanaman terberat $(60,97 \mathrm{~g})$, dan 100 biji terberat $(40,93 \mathrm{~g}$.)

\section{Pendahuluan}

Kacang tanah merupakan salah satu tanaman leguminose yang sangat berperan penting bagi kebutuhan pangan, tetapi memiliki nilai ekonomi yang tinggi sehingga banyak yang menjadikan kacang tanah selain bahan pangan juga sebagai bahan baku industri. Hal ini karena kandungan protein yang terdapat di dalamnya. Di Kabupaten Timor Tengah Utara (TTU), kacang tanah paling banyak ditanam di lahan kering. BPS TTU (2015.), bahwa produksi kacang tanah mengalami penurunan produksi dari tahun 2011 sampai 2015 berturut-turu sebesar 1,26t/ha, 1,15t/ha, 1,16t/ha, 1t/ha, 0,71t/ha. Kebutuhan dan permintaan kacang tanah terus meningkat dari tahun ke tahun namun tidak diimbangi dengan produksi kacang tanah. Salah satu penyebab rendahnya produktivitas ini adalah tingkat kesuburan tanah yang rendah dan jenis tanah tidak sesuai untuk budidaya kacang tanah. Penurunan tingkat kesuburan tanah diakibatkan oleh pengambilan hasil secara terus-menerus tanpa diimbangi dengan pengembalian hara tanah dan penggunaan pupuk anorganik dengan jumlah besar. Penurunan tingkat kesuburan tanah tersebut dapat dikendalikan dengan beberapa cara, salah satunya adalah dengan penggunaan pupuk organik.

Penambahan pupuk organik ke dalam lahan pertanian dapat dilakukan dengan memanfaatkan limbah kotoran ternak babi namun masih banyak petan yang belum menggunakan kotoran ternak babi sebagai bahan baku pupuk organik. Di Desa Bakitolas, Kecamatan Nai'benu, Kabupaten Timor Tengah Utara belum mengoptimalkan potensi kotoran ternak babi karena kebiasaan keluarga petani masih beternak secara tradisional yaitu dengan melepaskan babi begitu saja di areal yang diinginkan masyarakat petani sehingga kotoran dari ternak babi berhamburan begitu saja. Oleh karena itu guna memperbaiki kualitas tanah akibat penggunaan pupuk anorganik yang berlebihan dan meningkatkan produksi kacang tanah, sebaiknya memanfaatkan kelimpahan limbah dari ternak babi tersebut, selain mengurangi polusi udara juga mengajak masyarakat akan pentingnya penggunaan pupuk organik demi kelestarian lingkungan juga menjaga kestabilan tanah karena sifat dari pupuk organik itu sendiri adalah melepaskan unsur hara secara perlahan (slow release).

Pupuk kandang babi selain menyediakan unsur hara bagi tanaman juga dapat mengikat air sehingga aliran permukaan pada saat hujan dapat dikurang serta dapat meningkatkan hasil tanaman castanea (Zeng shu-cai et al., 2006). Yasa (2016), penggunaan pupuk kandang babi dengan dosis babi 10 ton/ha memberikan hasil tertinggi pada berat segar buah tomat. Takaran pupuk kandang babi dengan kisaran 20-25 t/ha dapat meningkatkan berat kering pipilan jagung dibandingkan dengan kontrol (Bhato, 2015). Nokas, et al., (2015), pupuk kandang babi yang diberikan pada lahan dengan takaran $15 \mathrm{t} / \mathrm{ha}$ menghasilkan berat kering biji kacang kedelai per petak sebesar 1,647 t/ha.

Peningkatan produksi tanaman selain sangat dipengaruhi oleh penggunaan pupuk, juga ditentukan oleh pengaturan jarak tanam. Mayadewi (2007), pada jarak tanam yang terlalu sempit menyebabkan tanaman budidaya akan memberikan hasil yang relatif kurang karena adanya kompetisi antar tanaman dalam menggunakan unsur hara, air, cahaya matahari dan ruang tumbuh. Namun pengaturan jarak tanam juga sangat tergantung pada kondisi tanah, seperti pada lahan kering yang tanahnya padat, berbatu dan kurang subur, perlu diatur aga jarak tanamnya optimal bagi pertumbuhan dan perkembangan tanaman sehingga produksi tanaman optimal juga. Pada kondisi kering jarak tanam yang renggang mengakibatkan tingkat penguapan tanah tinggi sehingga daya ikat air tanah sangat kurang, tetapi pada kondisi yang terlalu rapat pertumbuhan tanaman terganggu karena adanya kompetisi antar tanaman, baik ruang tumbuh maupun penyerapan unsur hara serta air untuk pertumbuhan dan produksinya. Marunnie (2007) menyatakan bahwa penentuan jarak tanam juga tergantung pada daya tumbuh benih, kesuburan tanah, musim dan varietas yang ditanam. Benih dapa ditanam pada jarak tanam yang lebih rapat apabila daya tumbuh benih agak rendah, pada tanah yang tandus, varietas yang batangnya tidak panjang dan penanaman pada musim kemarau, sedangkan benih dapat ditanam pada jarak tanam yang lebih renggang apabila ditanam pada tanah yang subur dan varietas yang banyak bercabang.

Jarak tanam yang rapat dapat menurunkan produksi tanaman per individu tetapi dapat meningkatkan produksi tanaman per satuan luas tertentu. Selain itu pertumbuhan gulma di bawah tajuk menjadi berkurang sehingga mengurangi kompetisi tanaman dengan gulma terhadap sumber daya air dan unsur hara. Hal ini diperkuat oleh pernyataan Suprapto (1988), keuntungan menggunakan jarak tanam rapat antara lain: (a) benih yang tidak tumbuh atau bila ada tanaman muda yang mati dapat terkompensasi sehingga tanaman tidak terlalu jarang; (b) permukaan tanah dapat segera tertutup sehingga pertumbuhan gulma dapa ditekan; dan (c) jumlah tanaman yang tinggi diharapkan dapat memberikan hasi yang tinggi pula. Sebaliknya jarak tanam yang terlalu rapat mempunyai beberapa kerugian, yaitu: (a) polong per tanaman berkurang sehingga hasil per hektar menjadi rendah; (b) ruas batang tumbuh menjadi lebih panjang sehingga tanaman kurang kokoh dan mudah roboh; (c) benih yang dibutuhkan lebih banyak dan (d) penyiangan sukar dilakukan.

Berbagai kajian tentang pengaturan jarak tanam telah dilakukan dan memperoleh produksi tanaman kacang tanah bervariasi pula. Menurut Suprapto (2004), kacang tanah yang ditanam dalam bentuk larikan pada lahan pertanian yang subur menggunakan jarak tanam $40 \mathrm{~cm} \times 15 \mathrm{~cm}$ atau $30 \mathrm{~cm} \times 20 \mathrm{~cm}$ sedangkan pada lahan pertanian yang kurang subur dapat ditanam lebih rapat 40 $\mathrm{cm} \times 10 \mathrm{~cm}$ atau $20 \mathrm{~cm} \times 20 \mathrm{~cm}$. Rahmawati (2017), jarak tanam yang tepat untuk tanaman kacang tanah adalah $40 \mathrm{~cm} \times 30 \mathrm{~cm}$ karena dapat meningkatkan pertumbuhan dan hasil kacang tanah. Usahatani kacang tanah yang paling menguntungkan dan efisien adalah menggunakan jarak tanam $30 \mathrm{~cm} \times 15 \mathrm{~cm}$ karena memiliki nilai $\mathrm{R} / \mathrm{C}$ ratio 1,93 (Herawati et al., 2014). Hidayat (2008), jarak tanam $20 \mathrm{~cm} \times 20 \mathrm{~cm}$ menghasilkan berat kering biji per tanaman lebih tinggi dibandingkan dengan jarak tanam $40 \mathrm{~cm} \times 10 \mathrm{~cm}$.

Pengaturan jarak tanam yang tepat akan berpengaruh terhadap pertumbuhan, kualitas dan kuantitas hasil tanaman. Selain itu kesuburan tanah juga perlu diperhatikan agar cukup tersedia hara bagi kebutuhan tanaman sehingga mengantisipasi tingginya tingkat kompetisi antar tanaman dalam menyerap unsur hara dari dalam tanah, dan juga untuk meningkatkan zona perakaran suatu tanaman, zona pertumbuhan suatu tanah dapat dikurangi. Dengan demikian tanaman dapat tumbuh dengan baik dan menghasilkan maksimal. Oleh karena itu dalam membudidayakan tanaman, seperti kacang tanah di lahan kering selain mengatur jarak tanam juga harus dilakukan penambahan hara melalui pemberian pupuk organik yang kaya akan unsur hara dapat mengikat air dan memperbaiki tekstur tanah. Tujuan dari penelitian in adalah untuk mengetahui jarak tanam dan takaran pupuk kandang babi yang tepat bagi pertumbuhan dan hasil tanaman kacang tanah di lahan kering.

\section{Metode}

Penelitian ini dilaksanakan pada bulan Desember 2016 sampai Maret 2017 di kebun percobaan Fakultas Pertanian, belakang Perpustakaan, Universitas Timor, Kelurahan Sasi, Kecamatan Kota Kefamenanu, Kabupaten Timor Tengah Utara menggunakan Rancangan Acak Kelompok (RAK) Faktorial yang terdiri dari dua faktor perlakuan, yaitu: faktor pertama, jarak tanam (J) dengan tiga taraf, yaitu: $\mathrm{J}_{1}=$ Jarak tanam $40 \times 20 \mathrm{~cm}, \mathrm{~J}_{2}=$ Jarak tanam $40 \times 30 \mathrm{~cm}, \mathrm{~J}_{3}=$ Jarak tanam $40 \times 40 \mathrm{~cm}$; faktor kedua, dosis pupuk kandang babi (B) dengan tiga taraf, yaitu: $\mathrm{B}_{0}=0 \mathrm{t} / \mathrm{ha}$ (kontrol), $\mathrm{B}_{1}=5 \mathrm{t} / \mathrm{ha}, \mathrm{B}_{2}=10 \mathrm{t} / \mathrm{ha}$.

Penelitian dimulai dengan persiapan lahan, gulma dan vegetasi lain dibersihkan kemudian lahan dibajak dengan menggunakan traktor, kemudian lahan dipetakan menjadi 3 blok. Setiap blok terdiri dari 9 petak dengan ukuran 1,3 $\mathrm{m} \times 2,1 \mathrm{~m}$. Lahan yang telah diolah diberi pupuk kandang babi sesuai dengan perlakuan, kemudian pupuk dicampur secara merata dengan tanah. Lahan yang telah dicampur dengan pupuk kandang babi diinkubasi selama 14 Hari Setelah Tanam (HST) kemudian benih ditanam dengan populasi benih per lubang tanam sebanyak 3 biji dan dijarangkan dengan menyisakan 2 tanaman per lubang 
tanaman pada saat tanaman berumur 14 HST. Panen dilakukan pada saat tanaman telah menunjukkan masak fisiologi dengan ciri daun telah mengering dan warna batang kecokelatan.

Parameter pengamatan yang diamati dalam penelitian ini adalah:

1. Suhu tanah $\left({ }^{\circ} \mathrm{C}\right)$

Pengukuran suhu tanah dilakukan dengan menancapkan termometer sedalam $5 \mathrm{~cm}$ pada siang hari $(12: 00$ - 14:00) selama 3 menit pada tiga titik sampel setiap petak. Pengamatan terhadap suhu tanah dilakukan pada saat tanaman telah berumur 14 HST kemudian dilanjutkan setiap 14 hari berikutnya. 2. Kadar Lengas Tanah

Pengamatan terhadap kadar lengas tanah dilakukan satu kali pada saa tanaman mencapai umur vegetatif maksimum yang ditandai dengan munculnya bunga pada tanaman. pengamatan dilakukan dengan cara mengambil sampel tanah sebanyak 3 titik sampel dalam setiap petak dengan cara mengambil tanah dari kedalaman $\pm 5 \mathrm{~cm}$, kemudian menimbang berat basah (BB) sampel tanah menggunakan timbangan analitik, mengeringkan sampel tanah menggunakan oven pada suhu $105^{\circ} \mathrm{C}$ selama \pm 16 jam sampai dengan mendapatkan berat konstan (berat kering akhir) dan dihitung menggunakan rumus :

Keterangan: $\mathrm{KL}=$ Kadar Lengas Tanah $(\%)$

$$
\text { Rumus: } \mathrm{KL}=\frac{\mathrm{BB}-\mathrm{BK}}{\mathrm{BK}} \times 100 \%
$$

$\mathrm{BB}=$ Berat Basah Tanah $(\mathrm{g})$

$\mathrm{BK}=$ Berat Kering Tanah $(\mathrm{g})$

\section{Berat volume}

Gumpalan tanah yang telah di oven ditimbang berat keringnya kemudian diikat dengan tali rafia sepanjang $10 \mathrm{~cm}$ dan dicelupkan ke dalam cairan lilin yang dipanaskan dengan lampu Bunsen. Gumpalan tanah yang telah dilapisi lilin dicelupkan ke dalam gelas ukur berisi air setinggi $40 \mathrm{ml}$, kenaikan volume air dicatat untuk dipergunakan dalam menghitung volume tanah dengan menggunakan rumus:

$$
\mathrm{BV}=\frac{\mathrm{B}}{\mathrm{V}}
$$

Keterangan: $\mathrm{BV}=$ berat volume tanah;

$$
\begin{aligned}
& \mathrm{B}=\text { Berat tanah kering; } \\
& \mathrm{V}=\text { Volume tanah }
\end{aligned}
$$

4. Tinggi tanaman $(\mathrm{cm})$

Tinggi tanaman diukur dari pangkal batang sampai ujung daun paling tinggi pengukuran menggunakan penggaris centimeter. Pengukuran dilakukan pada 3 tanaman sampel dalam setiap petak, pengukuran dilakukan pada saat tanaman berumur 14 HST, kemudian diulangi pada 14 hari berikutnya sampai tanaman berumur 68 HST.

5. Diameter batang $(\mathrm{mm})$

Diameter Batang diukur dari pangkal batang sampai ujung daun paling tinggi pengukuran menggunakan penggaris centimeter. Pengukuran dilakukan pada 3 tanaman sampel dalam setiap petak, pengukuran dilakukan pada saa tanaman berumur 14 HST, kemudian diulangi pada 14 hari berikutnya sampai tanaman berumur $68 \mathrm{HST}$.

6. Jumlah tangkai daun

Diameter Batang diukur dari pangkal batang sampai ujung daun paling tinggi pengukuran menggunakan penggaris centimeter. Pengukuran dilakukan pada 3 tanaman sampel dalam setiap petak, pengukuran dilakukan pada saat tanaman berumur 14 HST, kemudian diulangi pada 14 hari berikutnya sampai tanaman berumur 68 HST.

7. Panjang akar

Panjang akar diukur dari pangkal akar hingga ujung akar dengan menggunakan penggaris centimeter pada tanaman korban. Tanaman korban digali pada saat tanaman telah mencapai umur vegetatif maksimum

8. Bobot segar tanaman (vegetatif maksimum)

Bobot segar tanaman diukur menggunakan timbangan analitik. Sebelum ditimbang tanaman dibersihkan dari tanah dengan menggunakan air kemudian tanaman ditiriskan sampai semua kandungan air tidak menetes lagi.

9. Bobot kering tanaman (vegetatif maksimum)

Bobot kering tanaman diukur dengan cara tanaman di oven di dalam oven selama 48 jam dengan suhu $80{ }^{\circ} \mathrm{c}$ kemudian menimbang menggunakan timbangan analitik pada setiap tanaman korban.

10. Bobot Kering Daun

Dilakukan dengan cara menimbang semua daun pada tanaman korban bersamaan dengan berat kering tanaman namun dipisah dari tangkai daun dan batang tanaman.

11. Bobot kering akar dan batang

Setelah menimbang daun pada tanaman korban, selanjutnya dilakukan penimbangan terhadap batang tanaman dan akar.

12. Rasio Tajuk Akar

Rasio tajuk akar diperoleh dari hasil bagi antara bobot kering tajuk dengan bobot kering akar yang dapat dinyatakan atau dirumuskan dengan model:

Keterangan: $\quad \mathrm{S}-\mathrm{R}=$ Rasio tajuk akar;

$$
\mathrm{S}-\mathrm{R}=\frac{\mathrm{Bkt}}{\mathrm{Bka}}
$$

Bkt $=$ Bobot kering tajuk

Bka $=$ Bobot kering akar.
13. Jumlah bintil akar

Diukur dengan cara menghitung bintil akar pada setiap tanaman yang ada dalam bedeng 2 tanaman korban.

14. Jumlah bintil akar efektif

Bintil akar efektif dilihat dengan cara bintil akar di belah menggunakan silet dan akan di tandai dengan cairan berwarna kemerah-merahan pada tanaman korban

15. Luas daun $\left(\mathrm{cm}^{2}\right)$

Luas daun diukur saat pertumbuhan vegetatif maksimum yang di tandai dengan kacang tanah mulai berbunga pengukuran dilakukan pada tanaman korban. Pengamatan terhadap luas daun menggunakan metode image $\mathrm{J}$.

16. Berat segar berangkasan

Berat segar berangkasan diukur dengan cara menimbang berangkasan segar semua tanaman dalam setiap petak yang sudah dipanen menggunakan timbangan duduk kemudian di catat angkanya.

17. Berat kering berangkasan

Berat kering berangkasan diukur dengan cara menimbang semua berangkasan dalam setiap bedeng tanaman yang telah dipanen dan di oven selama 2 hari dengan suhu $80^{\circ} \mathrm{c}$ kemudian dikonversi kesatuan t/ha. Pengukuran menggunakan timbangan duduk.

18. Jumlah polong pertanaman

Dilakukan dengan cara menghitung polong yang terbentuk pada 3

tanaman sampel yang ada dalam setiap bedeng

19. Jumlah biji per polong

Menghitung biji dalam masing-masing polong yang terbentuk dalam 3 tanaman sampel yang ada di dalam setiap petak kemudian dirata-ratakan

20. Bobot biji pertanaman

Dilakukan dengan cara mengeringkannya di oven pada suhu $80^{\circ} \mathrm{C}$ selama 48 jam hingga mencapai berat konstan, dan menimbang berat keringnya menggunakan timbangan analitik.

21. Berat 100 biji

Menghitung 100 biji yang terbentuk pada saat pemanenan di setiap petak lalu ditimbang menggunakan timbangan analitik

22. Berat biji per petak

Menimbang semua biji yang terbentuk dalam setiap petak percobaan, selanjutnya dikonversi ke ton/ha.

23. Indeks panen

Indeks panen dihitung dengan cara membandingkan berat bagian tanaman yang bernilai ekonomis dengan berat seluruh bagian tanaman kemudian dikonversi ke satuan \%. Indeks panen dapat dihitung dengan rumus :

$$
\mathrm{IP}=\frac{\mathrm{A}}{\mathrm{A}+\mathrm{B}} \times 100 \%
$$

Keterangan: $\mathrm{A}=$ Bagian tanaman yang bernilai ekonomis;

$\mathrm{B}=$ Bagian tanaman yang tidak bernilai ekonomis;

$\mathrm{IP}=$ Indeks panen

Semua data yang dikumpulkan dianalisis dengan menggunakan analisis sidik ragam (Anova) Rancangan Acak Kelompok (RAK) pola faktorial. Selanjutnya rata- rata perlakuan diuji dengan menggunakan Duncan Multiple Range Test (DMRT) dengan tingkat signifikasi 5\% sesuai petunjuk Gomez, (1995.). Analisis data menggunakan program SAS 9.1.

\section{Hasil dan Pembahasan}

\subsection{Suhu Tanah $\left({ }^{\circ} \mathrm{C}\right)$}

Analisis sidik ragam (Anova) menunjukkan bahwa tidak terjadi interaksi dan beda nyata antar perlakuan terhadap pengamatan suhu tanah. Rata-rata suhu tanah cenderung menurun pada pengamatan 14-56 HST. Hal ini karena selain dipengaruhi oleh tajuk tanaman juga karena pupuk kandang yang diberikan. Rata-rata pengamatan 68 HST suhu tanah cenderung meningkat karena tajuk tanaman mulai mengering dan menggugurkan daunnya (Tabel 1).

\subsection{Kadar Lengas Tanah}

Analisis sidik ragam (Anova) menunjukkan bahwa tidak terjadi interaksi antar perlakuan terhadap pengamatan kadar lengas tanah. Masing-masing aras perlakuan, baik perlakuan jarak tanam maupun perlakuan dosis pupuk tidak berbeda nyata antar aras perlakuan (Tabel 2)

\subsection{Berat Volume Tanah}

Analisis sidik ragam (Anova) menunjukkan bahwa tidak terjadi interaksi dan beda nyata antar perlakuan terhadap pengamatan berat volume tanah. Ratarata BV tanah terbaik ditunjukkan pada jarak tanam $40 \times 20 \mathrm{~cm}$ dan dosis pupuk $10 \mathrm{t} /$ ha dibandingkan jarak tanam dan dosis pupuk lainnya (Tabel 3).

\subsection{Tinggi Tanaman}

Analisis sidik ragam (Anova) menunjukkan bahwa tidak terjadi interaksi antar perlakuan terhadap pengamatan tinggi tanaman. Perlakuan jarak tanam tidak berbeda nyata antar aras perlakuan pada pengamatan 14,28 , 68, namun pada umur 42 dan 56 terjadi beda nyata dengan jarak tanam paling rapat menghasilkan tinggi tanaman paling tinggi sedangkan perlakuan dosis pupuk menunjukkan beda nyata pada antar aras dari awal hingga akhir pengamatan pemberian dosis pupuk berbeda nyata dengan tanpa diberikan pupuk (Tabel 4). 
Tabel 1. Suhu Tanah

\begin{tabular}{|c|c|c|c|c|c|}
\hline \multirow{2}{*}{$\begin{array}{c}\text { Waktu } \\
\text { Pengamatan } \\
\text { (HST) }\end{array}$} & \multirow{2}{*}{$\begin{array}{l}\text { Jarak Tanaman- } \\
\qquad(\mathrm{cm})\end{array}$} & \multicolumn{3}{|c|}{ Dosis Pupuk (t/ha) } & \multirow[b]{2}{*}{ Rerata } \\
\hline & & Kontrol & 5 & 10 & \\
\hline \multirow{4}{*}{14} & $40 \times 20$ & 34,33 & 32,87 & 33,17 & $33,46 \mathrm{a}$ \\
\hline & $40 \times 30$ & 34,30 & 34,13 & 32,83 & $33,76 \mathrm{a}$ \\
\hline & $40 \times 40$ & 34,27 & 33,77 & 33,63 & $33,89 \mathrm{a}$ \\
\hline & Rerata & $34,30 \mathrm{a}$ & $33,59 \mathrm{a}$ & $33,21 \mathrm{a}$ & $(-)$ \\
\hline \multirow{4}{*}{28} & $40 \times 20$ & 32,00 & 33,10 & 32,27 & $32,46 \mathrm{a}$ \\
\hline & $40 \times 30$ & 32,23 & 32,43 & 32,37 & $32,34 \mathrm{a}$ \\
\hline & $40 \times 40$ & 32,37 & 31,47 & 30,77 & $31,53 \mathrm{a}$ \\
\hline & Rerata & $32,20 \mathrm{a}$ & $32,33 \mathrm{a}$ & $31,80 \mathrm{a}$ & $(-)$ \\
\hline \multirow{4}{*}{42} & $40 \times 20$ & 29,69 & 30,52 & 30,51 & $30,24 \mathrm{a}$ \\
\hline & $40 \times 30$ & 30,44 & 30,26 & 31,37 & $30,69 \mathrm{a}$ \\
\hline & $40 \times 40$ & 30,81 & 29,73 & 30,31 & $30,29 a$ \\
\hline & Rerata & $30,32 \mathrm{a}$ & $30,17 \mathrm{a}$ & $30,73 \mathrm{a}$ & $(-)$ \\
\hline \multirow{4}{*}{56} & $40 \times 20$ & 28,26 & 28,21 & 27,71 & $28,06 \mathrm{a}$ \\
\hline & $40 \times 30$ & 28,56 & 28,10 & 28,57 & $28,41 \mathrm{a}$ \\
\hline & $40 \times 40$ & 28,52 & 28,31 & 28,39 & $28,41 \mathrm{a}$ \\
\hline & Rerata & $28,44 \mathrm{a}$ & $28,21 \mathrm{a}$ & $28,22 \mathrm{a}$ & $(-)$ \\
\hline \multirow{4}{*}{68} & $40 \times 20$ & 32,68 & 34,66 & 34,92 & $34,09 \mathrm{a}$ \\
\hline & $40 \times 30$ & 33,50 & 35,36 & 34,40 & $34,42 \mathrm{a}$ \\
\hline & $40 \times 40$ & 34,18 & 34,88 & 35,16 & $34,74 \mathrm{a}$ \\
\hline & Rerata & $33,45 \mathrm{~b}$ & $34,96 \mathrm{a}$ & $34,83 \mathrm{a}$ & $(-)$ \\
\hline
\end{tabular}

Keterangan: Angka pada kolom dan baris diikuti huruf sama menunjukkan tidak berbeda pada tingkat nyata $(\alpha) 5$ menurut uji DMRT.(-) Tidak terjadi interaksi antar faktor

Tabel 2. Kadar Lengas Tanah

\begin{tabular}{ccccc}
\hline Jarak Tanaman & \multicolumn{3}{c}{ Dosis Pupuk (t/ha) } & \multirow{2}{*}{ Rerata } \\
\cline { 2 - 4 }$(\mathrm{cm})$ & Kontrol & 5 & 10 & \\
\hline $40 \times 20$ & 21,65 & 23,48 & 26,36 & $23,83 \mathrm{a}$ \\
$40 \times 30$ & 27,58 & 30,60 & 23,54 & $27,24 \mathrm{a}$ \\
$40 \times 40$ & 38,10 & 25,94 & 23,29 & $29,11 \mathrm{a}$ \\
Rerata & $29,11 \mathrm{a}$ & $26,67 \mathrm{a}$ & $24,40 \mathrm{a}$ & $(-)$
\end{tabular}

Keterangan: Angka pada kolom dan baris diikuti huruf sama menunjukkan tidak berbeda pada tingkat nyata $(\alpha) 5$ menurut uji DMRT.(-) Tidak terjadi interaksi antar faktor

Tabel 3. BV Tanah

\begin{tabular}{ccccc}
\hline Jarak Tanaman & \multicolumn{3}{c}{ Dosis Pupuk (t/ha) } & \multirow{2}{*}{ Rerata } \\
\cline { 2 - 4 }$(\mathrm{cm})$ & Kontrol & 5 & 10 & \\
\hline $40 \times 20$ & 1,13 & 1,19 & 1,17 & $1,16 \mathrm{a}$ \\
$40 \times 30$ & 1,20 & 1,20 & 1,17 & $1,19 \mathrm{a}$ \\
$40 \times 40$ & 1,36 & 1,18 & 1,16 & $1,23 \mathrm{a}$ \\
Rerata & $1,23 \mathrm{a}$ & $1,19 \mathrm{a}$ & $1,17 \mathrm{a}$ & $(-)$ \\
\hline
\end{tabular}

Keterangan: Angka pada kolom dan baris diikuti huruf sama menunjukkan tidak berbeda pada tingkat nyata $(\alpha) 5$ menurut uji DMRT.(-) Tidak terjadi interaksi antar faktor

Tabel 4. Tinggi Tanaman $(\mathrm{cm})$

\begin{tabular}{|c|c|c|c|c|c|}
\hline \multirow{2}{*}{$\begin{array}{c}\text { Waktu } \\
\text { Pengamatan } \\
\text { (HST) }\end{array}$} & \multirow{2}{*}{$\begin{array}{c}\text { Jarak } \\
\text { Tanaman } \\
(\mathrm{cm}) \\
\end{array}$} & \multicolumn{3}{|c|}{ Dosis Pupuk (t/ha) } & \multirow[b]{2}{*}{ Rerata } \\
\hline & & Kontrol & 5 & 10 & \\
\hline \multirow{4}{*}{14} & $40 \times 20$ & 3,61 & 4,28 & 3,50 & $3,80 \mathrm{a}$ \\
\hline & $40 \times 30$ & 3,94 & 4,11 & 3,44 & $3,83 \mathrm{a}$ \\
\hline & $40 \times 40$ & 4,14 & 4,00 & 3,67 & $3,94 \mathrm{a}$ \\
\hline & Rerata & $3,90 \mathrm{ab}$ & $4,13 \mathrm{a}$ & $3,54 \mathrm{~b}$ & $(-)$ \\
\hline \multirow{4}{*}{28} & $40 \times 20$ & 6,81 & 7,56 & 6,75 & $7,04 \mathrm{a}$ \\
\hline & $40 \times 30$ & 5,44 & 6,31 & 7,00 & $6,25 \mathrm{a}$ \\
\hline & $40 \times 40$ & 5,83 & 5,86 & 7,61 & $6,44 \mathrm{a}$ \\
\hline & Rerata & $6,03 \mathrm{~b}$ & $6,57 \mathrm{ab}$ & $7,12 \mathrm{a}$ & $(-)$ \\
\hline \multirow{4}{*}{42} & $40 \times 20$ & 13,25 & 18,94 & 18,97 & $17,06 \mathrm{a}$ \\
\hline & $40 \times 30$ & 13,63 & 15,56 & 17,72 & $15,64 \mathrm{ab}$ \\
\hline & $40 \times 40$ & 12,19 & 13,97 & 15,75 & $13,97 \mathrm{~b}$ \\
\hline & Rerata & $13,03 \mathrm{~b}$ & $16,16 \mathrm{a}$ & $17,48 \mathrm{a}$ & $(-)$ \\
\hline \multirow{4}{*}{56} & $40 \times 20$ & 19,03 & 24,97 & 25,69 & $23,23 \mathrm{a}$ \\
\hline & $40 \times 30$ & 17,39 & 21,14 & 23,42 & $20,65 \mathrm{ab}$ \\
\hline & $40 \times 40$ & 18,00 & 20,03 & 21,75 & $19,93 \mathrm{~b}$ \\
\hline & Rerata & $18,14 \mathrm{~b}$ & $22,05 \mathrm{a}$ & $23,62 \mathrm{a}$ & $(-)$ \\
\hline \multirow{4}{*}{68} & $40 \times 20$ & 25,33 & 34,81 & 35,75 & $31,96 \mathrm{a}$ \\
\hline & $40 \times 30$ & 22,97 & 31,36 & 33,28 & $29,20 \mathrm{a}$ \\
\hline & $40 \times 40$ & 25,58 & 28,86 & 33,39 & $29,28 \mathrm{a}$ \\
\hline & Rerata & $24,63 \mathrm{~b}$ & $31,68 \mathrm{a}$ & $34,14 \mathrm{a}$ & $(-)$ \\
\hline
\end{tabular}

Keterangan: Angka pada kolom dan baris diikuti huruf sama menunjukkan tidak berbeda pada tingkat nyata $(\alpha) 5$ menurut uji DMRT.(-) Tidak terjadi interaksi antar faktor
Tabel 5. Diameter Batang (mm)

\begin{tabular}{cccccc}
\hline Waktu & Jarak & \multicolumn{3}{c}{ Dosis Pupuk (t/ha) } & \\
\cline { 3 - 5 }$($ HST $)$ & $\begin{array}{c}\text { Tanaman } \\
(\mathrm{cm})\end{array}$ & Kontrol & 5 & 10 & Rerata \\
\hline \multirow{4}{*}{14} & $40 \times 20$ & 0,48 & 0,45 & 0,49 & $0,47 \mathrm{a}$ \\
& $40 \times 30$ & 0,45 & 0,44 & 0,46 & $0,45 \mathrm{a}$ \\
& $40 \times 40$ & 0,40 & 0,46 & 0,49 & $0,45 \mathrm{a}$ \\
& Rerata & $0,44 \mathrm{a}$ & $0,45 \mathrm{a}$ & $0,48 \mathrm{a}$ & $(-)$ \\
& $40 \times 20$ & 0,44 & 0,46 & 0,46 & $0,46 \mathrm{a}$ \\
28 & $40 \times 30$ & 0,46 & 0,47 & 0,46 & $0,46 \mathrm{a}$ \\
& $40 \times 40$ & 0,43 & 0,46 & 0,49 & $0,46 \mathrm{a}$ \\
& Rerata & $0,45 \mathrm{a}$ & $0,46 \mathrm{a}$ & $0,47 \mathrm{a}$ & $(-)$ \\
& $40 \times 20$ & 0,48 & 0,49 & 0,48 & $0,48 \mathrm{a}$ \\
42 & $40 \times 30$ & 0,49 & 0,48 & 0,48 & $0,48 \mathrm{a}$ \\
& $40 \times 40$ & 0,47 & 0,48 & 0,48 & $0,48 \mathrm{a}$ \\
& Rerata & $0,48 \mathrm{a}$ & $0,48 \mathrm{a}$ & $0,48 \mathrm{a}$ & $(-)$ \\
& $40 \times 20$ & 0,51 & 0,56 & 0,58 & $0,55 \mathrm{a}$ \\
56 & $40 \times 30$ & 0,56 & 0,59 & 0,62 & $0,59 \mathrm{a}$ \\
& $40 \times 40$ & 0,56 & 0,55 & 0,56 & $0,56 \mathrm{a}$ \\
& Rerata & $0,54 \mathrm{a}$ & $0,57 \mathrm{a}$ & $0,59 \mathrm{a}$ & $(-)$ \\
& $40 \times 20$ & 0,50 & 0,56 & 0,57 & $0,54 \mathrm{a}$ \\
68 & $40 \times 30$ & 0,52 & 0,57 & 0,58 & $0,55 \mathrm{a}$ \\
& $40 \times 40$ & 0,58 & 0,55 & 0,57 & $0,57 \mathrm{a}$ \\
& Rerata & $0,53 \mathrm{~b}$ & $0,56 \mathrm{ab}$ & $0,57 \mathrm{a}$ & $(-)$ \\
\hline
\end{tabular}

Keterangan: Angka pada kolom dan baris diikuti huruf sama menunjukkan tidak berbeda pada tingkat nyata ( $\alpha$ ) 5 menurut uji DMRT.(-) Tidak terjadi interaksi antar faktor

\subsection{Diameter Batang}

Analisis sidik ragam (Anova) menunjukkan bahwa tidak terjadi interaksi antar perlakuan terhadap pengamatan diameter batang. Pengaruh jarak tanam tidak menunjukkan beda nyata pada waktu pengamatan namun pada pemberian dosis pupuk $10 \mathrm{t} / \mathrm{ha}$ memberikan beda nyata pada pengamatan $68 \mathrm{HST}$ dibanding dosis pupuk $5 \mathrm{t} /$ ha dan kontrol (Tabel 5)

\subsection{Jumlah Tangkai}

Analisis sidik ragam (Anova) menunjukkan bahwa tidak terjadi interaksi antar perlakuan terhadap pengamatan jumlah tangkai. Rata-rata jumlah tangkai terbaik sangat bervariasi tergantung jarak tanaman dan dosis pupuk namun tidak menunjukkan beda nyata (Tabel 6).

Tabel 6. Jumlah Tangkai

\begin{tabular}{|c|c|c|c|c|c|}
\hline \multirow{2}{*}{$\begin{array}{c}\text { Waktu } \\
\text { Pengamatan } \\
\text { (HST) }\end{array}$} & \multirow{2}{*}{$\begin{array}{c}\text { Jarak Tanaman } \\
(\mathrm{cm})\end{array}$} & \multicolumn{3}{|c|}{ Dosis Pupuk (t/ha) } & \multirow[b]{2}{*}{ Rerata } \\
\hline & & Kontrol & 5 & 10 & \\
\hline \multirow{4}{*}{14} & $40 \times 20$ & 1,89 & 2,00 & 2,39 & $2,09 \mathrm{a}$ \\
\hline & $40 \times 30$ & 2,06 & 2,28 & 2,22 & $2,19 \mathrm{a}$ \\
\hline & $40 \times 40$ & 2,22 & 2,11 & 2,06 & $2,13 \mathrm{a}$ \\
\hline & Rerata & $2,06 \mathrm{a}$ & $2,13 \mathrm{a}$ & $2,22 \mathrm{a}$ & $(-)$ \\
\hline \multirow{4}{*}{28} & $40 \times 20$ & 6,50 & 6,44 & 6,11 & $6,35 \mathrm{a}$ \\
\hline & $40 \times 30$ & 5,97 & 5,50 & 5,94 & $5,81 \mathrm{a}$ \\
\hline & $40 \times 40$ & 5,11 & 5,72 & 6,22 & $5,69 \mathrm{a}$ \\
\hline & Rerata & $5,86 \mathrm{a}$ & $5,89 \mathrm{a}$ & $6,09 \mathrm{a}$ & $(-)$ \\
\hline \multirow{4}{*}{42} & $40 \times 20$ & 6,00 & 5,83 & 6,33 & $6,06 \mathrm{a}$ \\
\hline & $40 \times 30$ & 6,39 & 6,56 & 6,39 & $6,44 \mathrm{a}$ \\
\hline & $40 \times 40$ & 5,72 & 6,61 & 6,50 & $6,28 \mathrm{a}$ \\
\hline & Rerata & $6,04 \mathrm{a}$ & $6,33 \mathrm{a}$ & $6,41 \mathrm{a}$ & $(-)$ \\
\hline \multirow{4}{*}{56} & $40 \times 20$ & 10,94 & 11,78 & 12,28 & $11,67 \mathrm{a}$ \\
\hline & $40 \times 30$ & 10,44 & 11,17 & 11,50 & $11,04 \mathrm{a}$ \\
\hline & $40 \times 40$ & 10,89 & 11,44 & 10,00 & $10,78 \mathrm{a}$ \\
\hline & Rerata & $10,76 \mathrm{a}$ & $11,46 \mathrm{a}$ & $11,26 \mathrm{a}$ & $(-)$ \\
\hline \multirow{4}{*}{68} & $40 \times 20$ & 13,94 & 14,22 & 14,78 & $14,31 \mathrm{a}$ \\
\hline & $40 \times 30$ & 14,44 & 15,72 & 15,39 & $15,19 \mathrm{a}$ \\
\hline & $40 \times 40$ & 14,67 & 15,56 & 15,50 & $15,24 \mathrm{a}$ \\
\hline & Rerata & $14,35 \mathrm{a}$ & $15,17 \mathrm{a}$ & $15,22 \mathrm{a}$ & $(-)$ \\
\hline
\end{tabular}

Keterangan: Angka pada kolom dan baris diikuti huruf sama menunjukkan tidak berbeda pada tingkat nyata $(\alpha) 5$ menurut uji DMRT.(-) Tidak terjadi interaksi antar faktor

\subsection{Panjang Akar}

Terjadi interaksi antara perlakuan jarak tanam dengan perlakuan dosis pupuk. Kombinasi perlakuan jarak tanam 20×40 tanpa pupuk kandang menghasilkan akar tanaman paling panjang yaitu sebesar $12,96 \mathrm{~cm}$ yang berbeda nyata dengan kombinasi perlakuan lainnya. Hal ini diakibatkan oleh ketidak tersediaan hara di sekitar perakaran tanaman, terutama jarak tanam yang terlalu rapat sehingga terjadi kompetisi hara, air dan cahaya (Tabel 7). 
Tabel 7. Panjang Akar (cm)

\begin{tabular}{ccccc}
\hline \multirow{2}{*}{ Jarak Tanaman $(\mathrm{cm})$} & \multicolumn{3}{c}{ Dosis Pupuk (t/ha) } & \multirow{2}{*}{ Rerata } \\
\cline { 2 - 4 } & Kontrol & 5 & 10 & \\
\hline $40 \times 20$ & $12,96 \mathrm{a}$ & $10,88 \mathrm{~b}$ & $9,58 \mathrm{~b}$ & 11,14 \\
$40 \times 30$ & $9,04 \mathrm{~b}$ & $9,33 \mathrm{~b}$ & $9,93 \mathrm{~b}$ & 9,44 \\
$40 \times 40$ & $9,79 \mathrm{~b}$ & $9,54 \mathrm{~b}$ & $9,71 \mathrm{~b}$ & 9,68 \\
Rerata & 10,60 & 9,92 & 9,74 & $(+)$ \\
\hline
\end{tabular}

Keterangan: Angka pada kolom dan baris diikuti huruf sama menunjukkan tidak berbeda pada tingkat nyata $(\alpha) 5$ menurut uji DMRT. (+)Terjadi interaksi antar faktor

\subsection{Bobot Segar Tanaman}

Analisis sidik ragam (Anova) menunjukkan bahwa tidak terjadi interaks antar perlakuan terhadap pengamatan bobot segar tanaman. Pengaruh utama jarak tanaman tidak memberikan beda nyata namun pada jarak tanam $40 \times 20$ memiliki bobot berat segar tertinggi dibanding jarak tanam lainnya. Pemberian dosis pupuk 10 t/ha nyata memberikan pengaruhnya dibanding dosis pupuk 5 t/ha dan kontrol (Tabel 8)

Tabel 8. Bobot Segar Tanaman (g)

\begin{tabular}{ccccc}
\hline Jarak Tanaman & \multicolumn{3}{c}{ Dosis Pupuk (t/ha) } & \multirow{2}{*}{ Rerata } \\
\cline { 2 - 4 }$(\mathrm{cm})$ & Kontrol & 5 & 10 & \\
\hline $40 \times 20$ & 40,92 & 62,71 & 67,53 & $57,05 \mathrm{a}$ \\
$40 \times 30$ & 37,31 & 45,21 & 49,80 & $44,10 \mathrm{a}$ \\
$40 \times 40$ & 39,40 & 50,92 & 59,84 & $50,05 \mathrm{a}$ \\
Rerata & $39,21 \mathrm{~b}$ & $52,94 \mathrm{ab}$ & $59,05 \mathrm{a}$ & $(-)$ \\
\hline
\end{tabular}

Keterangan: Angka pada kolom dan baris diikuti huruf sama menunjukkan tidak berbeda pada tingkat nyata $(\alpha) 5$ menurut uji DMRT.(-) Tidak terjadi interaksi antar faktor

\subsection{Bobot Kering Tanaman}

Analisis sidik ragam (Anova) menunjukkan bahwa tidak terjadi interaksi antar perlakuan terhadap pengamatan bobot kering tanaman. Pengaruh utama jarak tanam tidak menunjukkan beda nyata namun rata-rata bobot kering tanaman paling berat terdapat pada jarak tanam $40 \times 20 \mathrm{~cm}$. Demikian pemberian pupuk tidak menunjukkan beda nyata namun pada dosis pupuk $10 \mathrm{t} / \mathrm{ha}$ memiliki rata-rata bobot kering tanaman tertinggi dibanding dosis 5 t/ha dan kontrol (Tabel 9).

Tabel 9. Bobot kering tanaman $(\mathrm{g})$

\begin{tabular}{ccccc}
\hline \multirow{2}{*}{ Jarak Tanaman $(\mathrm{cm})$} & \multicolumn{3}{c}{ Dosis Pupuk (t/ha) } & \multirow{2}{*}{ Rerata } \\
\cline { 2 - 4 } & Kontrol & 5 & 10 & \\
\hline $40 \times 20$ & 12,63 & 19,46 & 19,15 & $17,08 \mathrm{a}$ \\
$40 \times 30$ & 13,20 & 15,30 & 14,38 & $14,29 \mathrm{a}$ \\
$40 \times 40$ & 12,82 & 15,58 & 18,37 & $15,59 \mathrm{a}$ \\
Rerata & $12,88 \mathrm{a}$ & $16,78 \mathrm{a}$ & $17,30 \mathrm{a}$ & $(-)$ \\
\hline
\end{tabular}

Keterangan: Angka pada kolom dan baris diikuti huruf sama menunjukkan tidak berbeda pada tingkat nyata $(\alpha) 5$ menurut uji DMRT.(-) Tidak terjadi interaksi antar faktor

\subsection{Bobot Kering Daun}

Analisis sidik ragam (Anova) menunjukkan bahwa tidak terjadi interaksi antar perlakuan terhadap pengamatan bobot kering daun. Pengaruh utama jarak tanam tidak menunjukkan beda nyata namun rata-rata bobot kering daun paling berat terdapat pada jarak tanam $40 \times 40 \mathrm{~cm}$. Demikian pemberian pupuk tidak menunjukkan beda nyata namun pada dosis pupuk 10 t/ha memiliki rata-rata bobot kering daun tertinggi dibanding dosis 5 t/ha dan kontrol (Tabel 10).

Tabel 10. Bobot kering daun $(\mathrm{g})$

\begin{tabular}{ccccc}
\hline \multirow{2}{*}{ Jarak Tanaman $(\mathrm{cm})$} & \multicolumn{3}{c}{ Dosis Pupuk (t/ha) } & \multirow{2}{*}{ Rerata } \\
\hline $40 \times 20$ & 6,61 & 6,61 & 11,27 & $8,16 \mathrm{a}$ \\
$40 \times 30$ & 7,66 & 7,25 & 7,97 & $7,63 \mathrm{a}$ \\
$40 \times 40$ & 7,33 & 8,50 & 10,39 & $8,74 \mathrm{a}$ \\
Rerata & $7,20 \mathrm{a}$ & $7,46 \mathrm{a}$ & $9,88 \mathrm{a}$ & $(-)$ \\
\hline
\end{tabular}

Keterangan: Angka pada kolom dan baris diikuti huruf sama menunjukkan tidak berbeda pada tingkat nyata $(\alpha) 5$ menurut uji DMRT.(-) Tidak terjadi interaksi antar faktor

\subsection{Bobot Kering Akar + Batang}

Analisis sidik ragam (Anova) menunjukkan bahwa tidak terjadi interaksi antar perlakuan terhadap pengamatan bobot kering akar dan batang. Pengaruh utama jarak tanam tidak menunjukkan beda nyata namun rata-rata bobot kering akar dan batang paling berat terdapat pada jarak tanam $40 \times 20 \mathrm{~cm}$. Pemberian dosis pupuk $5 \mathrm{t} / \mathrm{ha}$ memiliki rata-rata bobot tertinggi tetapi tidak berbeda nyata pada dosis 10 t/ha dibanding kontrol (Tabel 11).

\subsection{Rasio Tajuk Akar}

Analisis sidik ragam (Anova) menunjukkan bahwa tidak terjadi interaksi antar perlakuan terhadap pengamatan rasio tajuk akar. Pengaruh utama jarak tanam tidak menunjukkan beda nyata namun pada jarak tanam yang lebih renggang cenderung meningkatkan rata-rata rasio tajuk akar. Demikian pemberian pupuk tidak menunjukkan beda nyata namun pada pemberian dengan level yang berbeda cenderung meningkatkan rasio tajuk akar (Tabel 12).

Tabel 11. Bobot Kering Akar dan Batang (g)

\begin{tabular}{ccccc}
\hline \multirow{2}{*}{ Jarak Tanaman $(\mathrm{cm})$} & \multicolumn{3}{c}{ Dosis Pupuk (t/ha) } & \multirow{2}{*}{ Rerata } \\
\hline $40 \times 20$ & 6,37 & 10,59 & 9,49 & $8,82 \mathrm{a}$ \\
$40 \times 30$ & 5,76 & 7,26 & 6,87 & $6,63 \mathrm{a}$ \\
$40 \times 40$ & 5,75 & 7,21 & 8,30 & $7,09 \mathrm{a}$ \\
Rerata & $5,96 \mathrm{~b}$ & $8,35 \mathrm{a}$ & $8,22 \mathrm{a}$ & $(-)$
\end{tabular}

Keterangan: Angka pada kolom dan baris diikuti huruf sama menunjukkan tidak berbeda pada tingkat nyata $(\alpha) 5$ menurut uji DMRT.(-) Tidak terjadi interaksi antar faktor

Tabel 12. Rasio tajuk akar

\begin{tabular}{ccccc}
\hline \multirow{2}{*}{ Jarak Tanaman $(\mathrm{cm})$} & \multicolumn{3}{c}{ Dosis Pupuk (t/ha) } & \multirow{2}{*}{ Rerata } \\
\cline { 2 - 4 } & Kontrol & 5 & 10 & \\
\hline $40 \times 20$ & 1,95 & 1,84 & 1,80 & $1,86 \mathrm{a}$ \\
$40 \times 30$ & 2,38 & 2,09 & 2,09 & $2,19 \mathrm{a}$ \\
$40 \times 40$ & 2,28 & 2,11 & 2,19 & $2,19 \mathrm{a}$ \\
Rerata & $2,20 \mathrm{a}$ & $2,01 \mathrm{a}$ & $2,03 \mathrm{a}$ & $(-)$ \\
\hline
\end{tabular}

Keterangan: Angka pada kolom dan baris diikuti huruf sama menunjukkan tidak berbeda pada tingkat nyata $(\alpha) 5$ menurut uji DMRT.(-) Tidak terjadi interaksi antar faktor

\subsection{Bintil Akar}

Analisis sidik ragam (Anova) menunjukkan bahwa tidak terjadi interaksi antar perlakuan terhadap pengamatan bintil akar. Pengaruh utama jarak tanam tidak menunjukkan beda nyata namun rata-rata bintil akar terbanyak terdapat pada jarak tanam yang terlalu rapat. Hal ini karena terjadi kompetisi yang mengakibatkan tanaman lebih banyak mengikat unsur Nitrogen dari udara karena ketidak tersediaan $\mathrm{N}$ di dalam tanah. Demikian pemberian dosis pupuk tidak menunjukkan beda nyata namun rata-rata tertinggi terdapat pada dosis $10 \mathrm{t} / \mathrm{ha}$ dibanding 5 t/ha dan kontrol (Tabel 13).

Tabel 13. Bintil Akar

\begin{tabular}{ccccc}
\hline \multirow{2}{*}{ Jarak Tanaman $(\mathrm{cm})$} & \multicolumn{3}{c}{ Dosis Pupuk (t/ha) } & \multirow{2}{*}{ Rerata } \\
\cline { 2 - 4 } & Kontrol & 5 & 10 & \\
\hline $40 \times 20$ & 67,83 & 88,33 & 125,50 & $93,89 \mathrm{a}$ \\
$40 \times 30$ & 44,67 & 96,33 & 88,33 & $76,44 \mathrm{a}$ \\
$40 \times 40$ & 55,00 & 95,00 & 77,33 & $75,78 \mathrm{a}$ \\
Rerata & $55,83 \mathrm{~b}$ & $93,22 \mathrm{a}$ & $97,06 \mathrm{a}$ & $(-)$ \\
\hline
\end{tabular}

Keterangan: Angka pada kolom dan baris diikuti huruf sama menunjukkan tidak berbeda pada tingkat nyata $(\alpha) 5$ menurut uji DMRT.(-) Tidak terjadi interaksi antar faktor

\subsection{Bintil Akar Efektif}

Analisis sidik ragam (Anova) menunjukkan bahwa tidak terjadi interaksi antar perlakuan terhadap pengamatan bintil akar efektif. Pengaruh utama jarak tanam tidak menunjukkan perbedaan yang nyata namun pada jarak yang terlalu rapat memiliki rata-rata bintil akar efektif terbanyak. Hal ini pula terkait dengan ketersediaan $\mathrm{N}$ di dalam tanah kurang memadai sehingga tanaman cenderung mengikat $\mathrm{N}$ dari udara. Pemberian dosis pupuk 10 t/ha menunjukkan beda nyata dan memiliki rata-rata bintil akar efektif terbanyak dibanding pemberian dosis pupuk 5 t/ha dan kontrol (Tabel 14).

Tabel 14. Bintil Akar Efektif

\begin{tabular}{|c|c|c|c|c|}
\hline \multirow{2}{*}{ Jarak Tanaman $(\mathrm{cm})$} & \multicolumn{3}{|c|}{ Dosis Pupuk (t/ha) } & \multirow{2}{*}{ Rerata } \\
\hline & Kontrol & 5 & 10 & \\
\hline $40 \times 20$ & 28,33 & 35,17 & 61,67 & $41,72 \mathrm{a}$ \\
\hline $40 \times 30$ & 22,83 & 33,50 & 44,00 & $33,44 \mathrm{a}$ \\
\hline $40 \times 40$ & 26,33 & 30,17 & 35,67 & $30,72 \mathrm{a}$ \\
\hline Rerata & $25,83 \mathrm{~b}$ & $32,94 \mathrm{ab}$ & $47,11 \mathrm{a}$ & $(-)$ \\
\hline
\end{tabular}

Keterangan: Angka pada kolom dan baris diikuti huruf sama menunjukkan tidak berbeda pada tingkat nyata $(\alpha) 5$ menurut uji DMRT.(-) Tidak terjadi interaksi antar faktor

\subsection{Luas Daun}

Analisis sidik ragam (Anova) menunjukkan bahwa tidak terjadi interaksi antar perlakuan terhadap pengamatan luas daun. Pengaruh utama jarak tanam tidak menunjukkan beda nyata namun rata-rata jarak tanam yang rapat memiliki permukaan daun yang lebih lebar dibanding jarak tanam yang renggang. Demikian pemberian dosis pupuk tidak menunjukkan beda nyata namun pada level pemberian yang berbeda cenderung memiliki permukaan daun yang lebih lebar (Tabel 15).

\subsection{Berat Segar Berangkasan (kg)}

Analisis sidik ragam (Anova) menunjukkan bahwa tidak terjadi interaksi antar perlakuan terhadap pengamatan berat segar berangkasan. Pengaruh utama jarak tanam nyata memberikan pengaruhnya, dimana jarak tanam $40 \times 20 \mathrm{~cm}$ memberikan bobot segar paling berat dibanding jarak tanam lainnya. Demikian 
pemberian dosis pupuk $10 t /$ ha menunjukkan beda nyata dibanding pemberian dengan dosis 5 t/ha dan kontrol (Tabel 16).

Tabel 15. Luas daun $\left(\mathrm{cm}^{2}\right)$

\begin{tabular}{ccccc}
\hline \multirow{2}{*}{ Jarak Tanaman $(\mathrm{cm})$} & \multicolumn{3}{c}{ Dosis Pupuk (t/ha) } & \multirow{2}{*}{ Rerata } \\
\cline { 2 - 4 } & Kontrol & 5 & 10 & \\
\hline $40 \times 20$ & 2,642 & 3,426 & 3,408 & $3,159 \mathrm{a}$ \\
$40 \times 30$ & 2,621 & 2,326 & 2,812 & $2,587 \mathrm{a}$ \\
$40 \times 40$ & 2,205 & 3,190 & 2,944 & $2,780 \mathrm{a}$ \\
Rerata & $2,489 \mathrm{a}$ & $2,981 \mathrm{a}$ & $3,055 \mathrm{a}$ & $(-)$ \\
\hline
\end{tabular}

Keterangan: Angka pada kolom dan baris diikuti huruf sama menunjukkan tidak berbeda pada tingkat nyata $(\alpha) 5$ menurut uji DMRT.(-) Tidak terjadi interaksi antar faktor

Tabel 16. Bobot Segar Berangkasan (kg)

\begin{tabular}{ccccc}
\hline \multirow{2}{*}{ Jarak Tanaman $(\mathrm{cm})$} & \multicolumn{3}{c}{ Dosis Pupuk (t/ha) } & \multirow{2}{*}{ Rerata } \\
\cline { 2 - 4 } & Kontrol & 5 & 10 & \\
\hline $40 \times 20$ & 1,72 & 2,63 & 2,84 & $2,40 \mathrm{a}$ \\
$40 \times 30$ & 1,12 & 1,36 & 1,49 & $1,32 \mathrm{~b}$ \\
$40 \times 40$ & 0,95 & 1,22 & 1,44 & $1,20 \mathrm{~b}$ \\
Rerata & $1,26 \mathrm{~b}$ & $1,74 \mathrm{ab}$ & $1,92 \mathrm{a}$ & $(-)$ \\
\hline
\end{tabular}

Keterangan: Angka pada kolom dan baris diikuti huruf sama menunjukkan tidak berbeda pada tingkat nyata $(\alpha) 5$ menurut uji DMRT.(-) Tidak terjadi interaksi antar faktor

\subsection{Bobot Kering Berangkasan (t/ha)}

Analisis sidik ragam (Anova) menunjukkan bahwa tidak terjadi interaksi antar perlakuan terhadap pengamatan bobot kering berangkasan. Perlakuan jarak tanam nyata memberikan pengaruhnya, dimana jarak tanam $40 \times 20 \mathrm{~cm}$ memberikan bobot kering berangkasan tertinggi. Hal ini dipengaruhi oleh populasi tanaman, jarak tanam yang sempit memiliki banyak populasi dibanding jarak tanam yang renggang. Demikian pemberian dosis pupuk tidak memberikan pengaruh nyata namun pada level pemberian yang berbeda cenderung meningkatkan bobot kering berangkasan (Tabel 17).

\subsection{Jumlah Polong Pertanaman}

Analisis sidik ragam (Anova) menunjukkan bahwa tidak terjadi interaksi antar perlakuan terhadap pengamatan jumlah polong pertanaman. Perlakuan jarak tanam, nyata memberikan pengaruhnya, dimana jarak tanam yang renggang $(40 \times 40 \mathrm{~cm})$ memiliki polong terbanyak dibanding jarak tanam yang sempit. Demikian pemberian dosis pupuk 10 t/ha nyata memberikan pengaruhnya dibanding pemberian dengan dosis $5 \mathrm{t} / \mathrm{ha}$ dan kontrol (Tabel 18).

Tabel 17. Bobot Kering Berangkasan (t/ha)

\begin{tabular}{ccccc}
\hline Jarak Tanaman & \multicolumn{3}{c}{ Dosis Pupuk (t/ha) } & \multirow{2}{*}{ Rerata } \\
\cline { 2 - 4 }$(\mathrm{cm})$ & Kontrol & 5 & 10 & \\
\hline $40 \times 20$ & 1,94 & 2,99 & 2,95 & $2,63 \mathrm{a}$ \\
$40 \times 30$ & 1,45 & 1,68 & 1,58 & $1,57 \mathrm{~b}$ \\
$40 \times 40$ & 1,13 & 1,37 & 1,61 & $1,37 \mathrm{~b}$ \\
Rerata & $1,51 \mathrm{a}$ & $2,01 \mathrm{a}$ & $2,05 \mathrm{a}$ & $(-)$ \\
\hline
\end{tabular}

Keterangan: Angka pada kolom dan baris diikuti huruf sama menunjukkan tidak berbeda pada tingkat nyata $(\alpha) 5$ menurut uji DMRT.(-) Tidak terjadi interaksi antar faktor

Tabel 18. Jumlah Polong Pertanaman

\begin{tabular}{ccccc}
\hline \multirow{2}{*}{ Jarak Tanaman $(\mathrm{cm})$} & \multicolumn{3}{c}{ Dosis Pupuk (t/ha) } & \multirow{2}{*}{ Rerata } \\
\cline { 2 - 4 } & Kontrol & 5 & 10 & \\
\hline $40 \times 20$ & 9,56 & 12,89 & 13,22 & $11,89 \mathrm{~b}$ \\
$40 \times 30$ & 12,33 & 16,22 & 20,00 & $16,19 \mathrm{ab}$ \\
$40 \times 40$ & 18,67 & 19,00 & 23,44 & $20,37 \mathrm{a}$ \\
Rerata & $13,52 \mathrm{~b}$ & $16,04 \mathrm{ab}$ & $18,89 \mathrm{a}$ & $(-)$ \\
\hline
\end{tabular}

Keterangan: Angka pada kolom dan baris diikuti huruf sama menunjukkan tidak berbeda pada tingkat nyata $(\alpha) 5$ menurut uji DMRT.(-) Tidak terjadi interaksi antar faktor

\subsection{Jumlah Biji Perpolong}

Analisis sidik ragam (Anova) menunjukkan bahwa tidak terjadi interaksi antar perlakuan terhadap pengamatan jumlah biji per polong. Pengaruh utama jarak tanam tidak menunjukkan beda nyata namun rata-rata tertinggi terdapat pada jarak tanam $40 \times 30 \mathrm{~cm}$ dibanding jarak tanam lainnya. Demikian pemberian pupuk tidak menunjukkan beda nyata, dimana rata-rata jumlah biji terbanyak terdapat pada tanpa pemberian pupuk (Tabel 19).

\subsection{Bobot Biji Pertanaman}

Analisis sidik ragam (Anova) menunjukkan bahwa tidak terjadi interaksi antar perlakuan terhadap pengamatan bobot biji pertanaman. Pada perlakuan jarak tanam yang lebih renggang nyata memberikan pengaruhnya dibanding jarak tanam yang sempit. Demikian pemberian dosis pupuk 10 t/ha nyata meningkatkan bobot biji tanaman tertinggi dibanding dosis 5 t/ha dan kontrol (Tabel 20).
Tabel 19. Jumlah Biji Perpolong

\begin{tabular}{ccccc}
\hline \multirow{2}{*}{ Jarak Tanaman $(\mathrm{cm})$} & \multicolumn{4}{c}{ Dosis Pupuk (t/ha) } \\
\cline { 2 - 5 } & Kontrol & 5 & 10 & \\
\hline $40 \times 20$ & 2,22 & 2,13 & 2,10 & $2,15 \mathrm{a}$ \\
$40 \times 30$ & 2,38 & 2,21 & 2,24 & $2,28 \mathrm{a}$ \\
$40 \times 40$ & 2,14 & 2,25 & 2,10 & $2,16 \mathrm{a}$ \\
Rerata & $2,25 \mathrm{a}$ & $2,20 \mathrm{a}$ & $2,15 \mathrm{a}$ & $(-)$ \\
\hline
\end{tabular}

Keterangan: Angka pada kolom dan baris diikuti huruf sama menunjukkan tidak berbeda pada tingkat nyata ( $\alpha$ ) 5 menurut uji DMRT.(-) Tidak terjadi interaksi antar faktor

Tabel 20. Bobot Biji Pertanaman (g)

\begin{tabular}{ccccc}
\hline \multirow{2}{*}{ Jarak Tanaman $(\mathrm{cm})$} & \multicolumn{3}{c}{ Dosis Pupuk (t/ha) } & \multirow{2}{*}{ Rerata } \\
\cline { 2 - 4 } & Kontrol & 5 & 10 & \\
\hline $40 \times 20$ & 31,50 & 32,97 & 36,21 & $33,56 \mathrm{~b}$ \\
$40 \times 30$ & 40,40 & 48,08 & 65,42 & $51,30 \mathrm{a}$ \\
$40 \times 40$ & 55,04 & 53,51 & 74,37 & $60,97 \mathrm{a}$ \\
Rerata & $42,31 \mathrm{~b}$ & $44,85 \mathrm{~b}$ & $58,67 \mathrm{a}$ & $(-)$ \\
\hline
\end{tabular}

Keterangan: Angka pada kolom dan baris diikuti huruf sama menunjukkan tidak berbeda pada tingkat nyata $(\alpha) 5$ menurut uji DMRT.(-) Tidak terjadi interaksi antar faktor

\subsection{Bobot 100 Biji}

Analisis sidik ragam (Anova) menunjukkan bahwa tidak terjadi interaksi antar perlakuan terhadap pengamatan bobot 100 biji. Pada perlakuan jarak tanam yang renggang $(40 \times 40 \mathrm{~cm})$ nyata memiliki bobot 100 biji paling berat dibanding dibanding jarak tanam lainnya. Demikian pemberian dosis pupuk tidak menunjukkan beda nyata namun pada level pemberian yang berbeda cenderung meningkatkan bobot 100 biji (Tabel 21).

Tabel 21. Bobot 100 Biji (g)

\begin{tabular}{ccccc}
\hline \multirow{2}{*}{ Jarak Tanaman $(\mathrm{cm})$} & \multicolumn{3}{c}{ Dosis Pupuk (t/ha) } & \multirow{2}{*}{ Rerata } \\
\cline { 2 - 4 } & Kontrol & 5 & 10 & \\
\hline $40 \times 20$ & 36,42 & 36,78 & 37,55 & $36,92 \mathrm{~b}$ \\
$40 \times 30$ & 37,64 & 41,33 & 38,18 & $39,05 \mathrm{ab}$ \\
$40 \times 40$ & 39,26 & 40,65 & 42,81 & $40,90 \mathrm{a}$ \\
Rerata & $37,77 \mathrm{a}$ & $39,59 \mathrm{a}$ & $39,51 \mathrm{a}$ & $(-)$ \\
\hline
\end{tabular}

Keterangan: Angka pada kolom dan baris diikuti huruf sama menunjukkan tidak berbeda pada tingkat nyata $(\alpha) 5$ menurut uji DMRT(-) Tidak terjadi interaksi antar faktor

\subsection{Bobot Biji Perpetak (t/ha)}

Analisis sidik ragam (Anova) menunjukkan bahwa tidak terjadi interaksi antar perlakuan terhadap pengamatan bobot biji perpetak. Pada jarak tanam yang sempit nyata memberikan bobot biji paling berat namun tidak berbeda nyata pada jarak tanam yang lebih renggang. Demikian pemberian dosis pupuk $10 \mathrm{t} / \mathrm{ha}$ menunjukkan bobot biji perpetak paling berat tetapi tidak beda nyata dengan pemberian $5 \mathrm{t} /$ ha dibanding kontrol (Tabel 22).

Tabel 22. Bobot Biji Per petak (t/ha)

\begin{tabular}{ccccc}
\hline Jarak Tanaman & \multicolumn{3}{c}{ Dosis Pupuk (t/ha) } & \multirow{2}{*}{ Rerata } \\
\cline { 2 - 4 }$(\mathrm{cm})$ & Kontrol & 5 & 10 & \\
\hline $40 \times 20$ & 1,49 & 1,51 & 1,84 & $1,61 \mathrm{a}$ \\
$40 \times 30$ & 0,97 & 1,60 & 1,44 & $1,34 \mathrm{~b}$ \\
$40 \times 40$ & 1,21 & 1,63 & 1,89 & $1,57 \mathrm{ab}$ \\
Rerata & $1,22 \mathrm{~b}$ & $1,58 \mathrm{a}$ & $1,72 \mathrm{a}$ & $(-)$ \\
\hline
\end{tabular}

Keterangan: Angka pada kolom dan baris diikuti huruf sama menunjukkan tidak berbeda pada tingkat nyata $(\alpha) 5$ menurut uji DMRT.(-) Tidak terjadi interaksi antar faktor

\subsection{Indeks Panen}

Analisis sidik ragam (Anova) menunjukkan bahwa tidak terjadi interaksi antar perlakuan terhadap pengamatan indeks panen. Pada jarak tanam yang renggang $(40 \times 40)$ nyata memberikan indeks panen tertinggi dibanding jarak tanam lainnya. Demikian pada pemberian dosis pupuk tidak menunjukkan beda nyata namun pada level pemberian yang berbeda cenderung meningkatkan indeks panen, dimana rata-rata tertinggi terdapat pada pemberian dengan dosis 10 t/ha (Tabel 23).

Tabel 23. Indeks Panen (\%)

\begin{tabular}{ccccc}
\hline Jarak Tanaman & \multicolumn{3}{c}{ Dosis Pupuk (t/ha) } & \multirow{2}{*}{ Rerata } \\
\cline { 2 - 4 }$(\mathrm{cm})$ & Kontrol & 5 & 10 & \\
\hline $40 \times 20$ & 44,25 & 33,56 & 44,84 & $40,88 \mathrm{~b}$ \\
$40 \times 30$ & 41,54 & 49,07 & 47,97 & $46,20 \mathrm{ab}$ \\
$40 \times 40$ & 51,20 & 55,43 & 54,96 & $53,86 \mathrm{a}$ \\
Rerata & $45,66 \mathrm{a}$ & $46,02 \mathrm{a}$ & $49,26 \mathrm{a}$ & $(-)$ \\
\hline
\end{tabular}

Keterangan: Angka pada kolom dan baris diikuti huruf sama menunjukkan tidak berbeda pada tingkat nyata $(\alpha) 5$ menurut uji DMRT.(-) Tidak terjadi interaksi antar faktor 


\subsection{Pembahasan}

Tanaman kacang tanah yang diberi pupuk kandang babi pertumbuhannya jauh lebih baik dibandingkan dengan kacang tanah yang tidak diberi pupuk kandang babi (kontrol).Hasil penelitian menunjukkan bahwa kacang tanah yang diberi pupuk kandang babi dengan takaran 10t/ha dapat meningkatkan pertumbuhan tanaman kacang tanah yang dapat diekspresikan dalam bentuk diameter batang, jumlah tangkai daun, berat kering daun, rasio tajuk akar, dan hasil (jumlah polong/tanaman, bobot biji/tanaman, berat 100 biji, dan indeks panen)dibandingkan 5t/ha, dan kontrol, hal ini senada dengan pernyataan Bhato (2015) bahwa pemberian pupuk kandang babi mampu meningkatkan hasil panen kedelai secara signifikan. Selanjutnya Bhato (2015) menyatakan bahwa pemberian pupuk kandang babi 20 sampai 25 t/ha meningkatkan, hasil pipilan jagung per hektar lebih tinggi dari kontrol. Selanjutnya Berek (2016) menyatakan bahwa pemberian pupuk kandang babi dengan takaran $35 \mathrm{t} \mathrm{ha}^{-1}$ memberikan hasil umbi wortel tertinggi yakni sebesar $30,95 \mathrm{t} \mathrm{ha}^{-1}$.

Pengaturan jarak tanam $40 \mathrm{~cm} \times 40 \mathrm{~cm}$ memberikan ruang gerak tanaman terbaik, sehingga pertumbuhan tanaman lebih sehat dan pada akhirnya diperoleh hasil biji kering kacang tanah paling tinggi, yakni sebanyak 1,61t/ha. Hal ini disebabkan oleh rendahnya kompetisi di dalam sistem pertanaman baik kompetisi diatas tanah maupun kompetisi di dalam tanah. Pima, (2000) menyatakan bahwa tanaman dengan jarak yang lebih luas mendapatkan sinar matahari dan unsur hara yang cukup karena persaingan antar tanaman lebih kecil. Andrade, et al.,(2002) Peningkatan produksi tanaman juga diakibatkan oleh pengaturan jarak tanam karena persentase peningkatan produksi per lahan secara nyata ditentukan oleh persentase peningkatan intersepsi cahaya.

Pertumbuhan tanaman yang baik tersebut didukung oleh kondisi lingkungan yang optimal, fluktuasi suhu dalam tanah akan berpengaruh langsung terhadap aktivitas pertanian terutama proses perakaran tanaman di dalam tanah. Apabila suhu tanah naik akan berakibat berkurangnya kandungan air dalam tanah sehingga unsur hara sulit diserap tanaman. Sebaliknya jika suhu tanah rendah maka akan semakin bertambahnya kandungan air dalam tanah, dimana sampai pada kondisi ekstrim terjadi pengkristalan. Akibatnya aktivitas akar atau respirasi semakin rendah mengakibatkan translokasi dalam tubuh tanaman jadi lambat sehingga proses distribusi unsur hara jadi lambat dan akhirnya pertumbuhan tanaman jadi lambat. Demikian pula dengan suhu yang terlalu tinggi terjad aktivitas negatif seperti terjadi pembongkaran atau perusakan organ. Suhu maksimal dan minimal berpengaruh terhadap hasil produksi. Hal inilah yang menyebabkan hasil panen kacang tanah menjadi rendah. Oleh karena itu pengaturan jarak tanam sangat mendukung pertumbuhan tanaman dan produksi dan sangat berpengaruh terhadap kondisi iklim mikro di sekitar tanaman dan penerimaan sinar matahari. Jarak tanam yang rapat dapat menyebabkan kelembapan udara yang tinggi di sekitar tanaman. Kondisi ini tidak menguntungkan untuk pertumbuhan tanaman karena tanaman mudah terserang penyakit (Cahyono,2003.)

\section{Simpulan}

Tidak terjadi interaksi pengamatan antara perlakuan takaran pupuk kandang babi dan jarak tanam terhadap semua parameter kecuali pada parameter panjang akar. Pemberian pupuk kandang babi dengan takaran 10 t/ha menghasilkan biji kering per hektar paling tinggi yang berbeda nyata dengan kontrol. Pengaturan tanaman dengan jarak tanam $40 \mathrm{~cm} \times 40 \mathrm{~cm}$ menghasilkan jumlah polong per tanaman, berat kering biji per tanaman, dan berat 100 biji lebih tinggi.

\section{Pustaka}

Ahmed, S.I., Mickelson, S.K., Pederson, C.H., Baker, J.L., Kanwar, R.S., Lorimor, J.C \& Webber, D.F., 2013. Swine manure rate, timing, and application method effects on post-harvest soil nutrients, crop yield, and potential water quality implications in a corn-soybean rotation. Trans. ASABE 56:395-408.

Andrade, F.H, P. Calvino, A.Carilo and P. Barbieri., 2002. Yield response to narrow row depend

Beets, W. C. 1982. Multiple Cropping and Tropical Farming Systems. Gower Publishing Company Limited. England.

Berek., I.Y., Pengaruh Takaran Pupuk Kandang Babi dan Jarak Tanam Terhadap Pertumbuhan dan Hasil Wortel (Daucus carota, L.). Savana Cendana 1 (2) 63-67 (2016)

Bhato,M.A., 2015 Respon Pertumbuhan dan Hasil Jagung (Zea mays, L.) Varietas Pioner Terhadap Berbagai Takaran Pupuk Kandang Babi dan Jarak Tanam., Savana Cendana 1 (2) 85-89

BPS TTU. 2015. Timor Tengah Utara Dalam Angka. BPS TTU. Kefamenanu.

Cahyono, B., 2003. Kacang Buncis Teknik Budi Daya dan Analisis Usaha Tani. Kanisius. Yogyakarta. Hal : 42.

Chang, T.H. 1968. Climate and Agriculture an Ecological Survey. Aldin Publishing Company. Chicago. 296p.

Gomez, K. A. dan Gomez, A. A. 1995. Prosedur Statistik Untuk Penelitian Pertanian. Edisi ke 2. UI Press: Jakarta.

Herawati, N. Sudarto dan B.T.R. Erawati. 2014. Kajian Variasi Jarak Tanam terhadap Produktivitas Kacang Tanah di Lahan Kering. Prosiding Seminar Hasil Penelitian Tanaman Aneka Kacang dan Umbi 2014.
Mayadewi, N. N. A. 2007. Pengaruh Jenis Pupuk Kandang dan Jarak Tanam terhadap Pertumbuhan Gulma dan Hasil Jagung Manis. Jurnal Agritrop 26 (4) : $153-159$

Murinnie, E.D. 2007. Analisis Pertumbuhan Kacang Tanah dan Pergeseran Komposisi Gulma pada Frekuensi Penyiangan dan Jarak Tanam Yang Berbeda. Laporan Penelitian. Staf Pengajar Fakultas Pertanian Universitas Muria Kudus.

Hidayat, N. 2008. Pertumbuhan dan Produksi Kacang Tanah (Arachis hypogea L.) Varietas Lokal Madura Pada Berbagai Jarak Tanam Dan Dosis Pupuk Fosfor. Agrovigor 1(01): 55-64

Nokas, Y., Roberto I. C. O.T \& Maria, A.L. 2015. Pengaruh Waktu Aplikasi dan Dosis Pupuk Kandang Babi Terhadap Pertumbuhan dan Hasil Tanaman Kacang Kedelai (Glycine max,(L.)Merr.) Savana Cendana 1 (02): 31-37.

Pima, D. 2009. Pengaruh Sistem Jarak Tanam dan Metode Pengendalian Gulma Terhadap Pertumbuhan dan Produksi. Serial online (http://repository.usu.ac.id/bitstream/123456789/7592/1/09E01219.pdf). diakses pada tanggal 3 April 2014. Pukul 22.00 Wib.

Rahmawati. 2017. Pengaruh Beberapa Jarak Tanam terhadap Pertumbuhan dan Hasil Tanaman Kacang Tanah Varietas Kelinci (Arachis hypogeae L.). Jurnal Pertanian Faperta UMSB 1(01) 2017: 9-16.

Suprapto, H.S. 1998. Budidaya Kacang Tanah. Jakarta: PenebarSwadaya.

Yasa. I.P.A.S., Luh K. \& Ida. B.K.M. 2016. Pengaruh Dosis Pupuk Kandang Babi dan Biourine Sapi Terhadap Hasil dan Pertumbuhan Tanaman Tomat (Solanum lycopercium L.). http://repository.warmadewa.ac.id

Zeng shu-cai., Chen b., Jiang c. \& Wu Q. 2006. Impact of fertilization on chestnut growth, $\mathrm{N}$ and $\mathrm{P}$ concentrations in run off water on degraded slope land in South China. 